\title{
PENGARUH MODEL PROBLEM BASED LEARNING DAN KEMAMPUAN BERPIKIR KREATIF TERHADAP HASIL BELAJAR SEJARAH DI SMA KORPRI BEKASI
}

\author{
Muhammad Irham Romadhon *, Sarkadi, Abdul Syukur
}

\section{muhammadirham313@gmail.com}

Universitas Negeri Jakarta, Indonesia.

\begin{abstract}
This research aims to find out the effects of Problem Based Learning ( $P B L$ ) and creative thinking skills on the instructional outcomes of the history of students at SMA KORPRI Bekasi. This research is a quantitative study using an experimental design of $2 \times 2$. The population consists of all students of class XIIS at SMA KORPRI Bekasi. The sample in this research consists of two classes, namely class XIIS 1 and XIIS 2 with a total of 60 students. A multiple-choice test was administered to measure students' learning outcomes on history. A questionnaire was also used to uncover and categorize students' creative thinking. The results of this study indicate that: (1) students who were given problem-based learning models had higher learning outcomes in history compared to those who were given the direct learning models during historical instruction, (2) there was an interaction effect of learning models and creative thinking, (3) students who were given PBL and have high creative thinking skills had higher learning outcomes compared to those who were given a direct learning model and had high creative thinking skills, and (4) interestingly, a student with lower critical thinking skills got lower learning outcomes with PBL comparing those who had lower critical thinking skills and were given direct learning model. Hence, the result of this study indicates that there was an influence of the PBL model and creative thinking on the students learning outcomes in historical instruction at SMA KORPRI Bekasi.
\end{abstract}

Keywords: creative thinking, historical learning outcomes, problem-based learning models

\section{PENDAHULUAN}

Edukasi adalah hak bagi tiap manusia. Pendidikan berfungsi untuk mengembangkan kemampuan siswa dan menanamkan karakter yang baik pada diri tiap siswa. Selain itu, pendidikan memilki tujuan untuk mengembangkan potensi di dalam diri manusia. Dalam konteks Indonesia saat ini, pendidikan memiliki posisi dan makna penting karena merupakan sarana untuk mencerdaskan kehidupan bangsa sesuai dengan amanat konstitusi. 
Pendidikan tentu saja tak lepas dari kegiatan pembelajaran yang nantinya akan turut menentukan hasil belajar. Belajar dalam konteks ini mempunyai beberapa prinsip di antaranya kesiapan belajar, motivasi, perhatian, keaktifan siswa, perbedaan individual, siswa mengalami sendiri, pengulangan, materi pelajaran yang menantang, serta pemberian umpan balik dan penguatan (Basri, 2013).

Motivasi sangat diperlukan untuk menunjang proses pembelajaran yang baik agar dapat mencapai sasaran yang diinginkan. Motivasi berguna sebagai stimulus bagi siswa agar memperoleh pencapaian sebagai hasil dari pembelajaran. Motivasi yang biasanya mudah memacu siswa untuk memperoleh pencapaian yang diinginkan adalah melalui pemberian umpan balik. Melalui pemberian umpan balik berupa penilaian dan korekasi, guru dapat memastikan bahwa siswa berada di jalur yang sudah benar (Reid, 2007).

Dalam hubungannya dengan pelajaran sejarah, Kuntowijoyo (2013) mengemukakan bawa yang sering terjadi dalam pembelajaran adalah siswa hanya harus menghafal fakta-fakta kering seperti tahun, peristiwa, tempat, dan tokoh sehingga seringkali mengabaikan makna atau arti dari berbagai peristiwa sejarah. Padahal, makna inilah yang merupakan esensi dari pembelajaran sejarah agar selalu aktual dan relevan dengan perkembangan di masa kini dan di masa mendatang. Lebih lanjut ia mengungkapkan bahwa untuk jenjang sekolah menengah atas, pelajaran sejarah sebaiknya diberikan secara kritis. Pada jenjang ini, siswa diharapkan memiliki kemampuan untuk bisa berpikir panjang mengapa sesuatu peristiwa terjadi di masa lalu, dan ke mana tujuan kejadian-kejadian itu. Dengan demikian, mereka tidak akan terjebak pada pembelajaran yang kering dan tidak bermakna (Widja, 2018).

Siswa seringkali kurang bersemangat ketika proses pembelajaran sejarah berlangsung (Sayono, 2015). Pada umumnya siswa kurang merespon pertanyaan yang diajukan guru. Masalah ini menjadi tantangan bagi para guru sejarah dalam mengajar terutama dalam penyampaikan materi. Sebaiknya guru tidak melulu menggunakan satu atau dua model pembelajaran tertentu. Yang seringkali terjadi adalah guru asyik menjelaskan materi, sementara siswa-siswa di kelas hanya duduk mendengarkan. Oleh karenanya, kurang ada interaksi yang edukatif dalam pembelajaran sejarah di kelas. Selain itu, jumlah siswa yang aktif pada umumnya lebih sedikit dibandingkan dengan siswa yang pasif. Padahal belajar dapat dilakukan dengan cara learning by doing. Perlu diingat pula bahwa membelajarkan merupakan aktivitas yang melibatkan kegiatan mengarahkan peserta didik dan memudahkan mereka untuk mengetahui bagaimana cara menemukan sesuatu. Tentu saja kegiatan membelajarkan ini perlu disesuaikan dengan kompetenasi dan kapabilitas masing-masing pendidik. Dengan demikian, para siswa di kelas tidak hanya mendengar guru (Tirtarahardja \& La Sulo, 2005), sehingga hasil belajar yang diingankan bisa tercapai.

Hasil belajar dalam konteks ini adalah berubahnya perilaku seseorang peseta didik sebagi akibat dari adanya interaksi dengan peserta didik lainnya ataupun dengan pendidik atau guru, dan interaksi antara peserta didik dengan lingkungan belajarnya yang merupakan hasil dari kegiatan 
pembelajaran yang diikuti dan dialaminya (Suprijono, 2009). Dengan kata lain, belajar merupakan perubahan yang diraih seorang melalui suatu kegiatan pembelajaran.

Belajar merupakan kegiatan psikis atau mental yang terjadi dalam hubungan timbal balik yang aktif antara pebelajar dengan keadaan sekitarnya. Hal ini kemudian akan mendatangkan berbagai perubahan dalam diri peserta didik, terutama dalam ranah pengetahuan, pemahaman, kecakapan maupun sikap. Perlu dicatat bahwa berbagai macam perubahan yang terjadi tersebut bersifat relatif tetap (Winkel, 2005). Dengan demikian, tanda bahwa peserta didik atau siswa sudah belajar adalah adanya terjadinya perubahan kelakuan pada peserta didik atau siswa tersebut, sebagai contoh yang tadinya tidak mengerti menjadi mengerti.

Bloom mengklasifikasi learning outcomes menjadi tiga unsur. Pertama, unsur kognitif yang terkait dengan kesanggupan intelektual seseorang. Dalam hal ini, hasil belajar pada ranah kognitif terkait dengan kegiatan berpikir seperti menginggat, memahami, menerapkan, menganalisa sintesis dan evaluasi. Kedua, unsur afektif yang terkait dengan sikap, emosi, nilai, dan perasaan. Ada berbagai tingkatan pada ranah ini, mulai dari penerimaan, penanggapan penilaian, pengorganisasian, dan karakterisasi nilai. Ketiga, unsur psikomotorik, yaitu unsur yang terkait dengan kesanggupan yang menyangkut gerakan-gerakan otot (Siregar \& Nara, 2010).

Terkait dengan pemaparan di atas, peneliti melakukan observasi awal di SMA KORPRI Bekasi. Dari kegiatan ini, peneliti mendapati bahwa pada waktu pembelajaran sedang berjalan, para siswa kurang mencermati pemaparan guru. Sebagai contoh, ketika guru memberikan soal para siswa tidak mampu menjawab. Contoh yang lain adalah saat guru memaparkan materi, sebagian besar siswa kurang mempunyai motivasi untuk mengikuti pelajaran. Dalam hal metode, guru sejarah di sekolah ini masih menitikberatkan pada metode yang cenderung konvensional konvensional, seperti ceramah ataupun pembelajaran langsung.

Usaha yang bisa dilakukan oleh pendidik dalam menanggulangi problematika tersebut salah satunya ialah dengan menerapkan PBL. Model ini dapat membantu siswa untuk meningkatkan keterampilan yang diperlukan. PBL awalnya diperkenalkan Howard Barrows sekitar tahun 1970-an pada kegiatan belajar mengajar ilmu medis di McMaster University Canada (Newman, 2005).

PBL memfokuskan pada penyajian problematika riil kepada para peserta didik di awal pelajaran. Selanjutnya, siswa diajak untuk menyelesaikan masalah tersebut melalui proses penyelidikan. Menurut Dolmans dan Schmidt, seperti yang dikutip Newman (2005), PBL adalah satu di antara model pembelajaran yang dipakai dalam menaikkan tingkatan berpikir menuju tingkat yang lebih tinggi tinggi karena berorientasikan pada masalah. Dalam konteks ini, siswa juga belajar bagaimana belajar. Dalam PBL, proses berpikir diperlukan untuk memecahkan problem selama proses pembelajaran berlangsung. Problem yang disajikan kepada siswa-siswa ini haruslah berhubungan dengan materi pembelajaran untuk menantang siswa agar berpikir pada tingkat yang lebih tinggi guna memecahkan problem yang dihadapi.

Model PBL memakai permasalahan riil sebagai konteks bagi siswa-siswa agar dapat belajar untuk berpikir kreatif, inovatif dan mampu memecahkan problem serta untuk mendapatkan 
pengetahuan maupun konsep inti yang penting dari materi pelajaran. Perlu diingat bahwa model pembelajaran PBL merupakan salah satu model yang dianjurkan pada penerapan kurikulum dan proses pembelajaran. Dalam kurikulum 2013, ada berbagai problematika yang sengaja dirancang untuk menuntut siswa memperoleh pengetahuan yang penting, serta menyebabkan para siswa menjadi lebih cakap dalam pemecalah masalah serta memiliki strategi belajar mandiri dan mempunyai kemampuan untuk berpartisipasi dalam tim (Amir, 2009).

Kemampuan berpikir kreatif (creative thinking) siswa juga sangat berperan penting untuk membantu siswa dalam menerapkan model pembalajaran ini. Torrance berpandangan bahwa creative thinking merupakan proses yang melibatkan berbagai unsur fleksibilitas, orisinalitas, kelancaran serta elaborasi (Susanto, 2013). Berpikir kreatif melibatkan kegiatan mental yang menantang individu untuk menjadi sensitif menyadari berbagai problematika yang ada di sekitarnya dan celah atau kekurangan dalam pengetahuan.

Kreativitas muncul bersamaan dengan lahirnya manusia. Kata kreatif seringakli disejajarkan dengan kreasi, mencipta, dan kreatif. Asal kata kreasi terkait dengan produk asli atau penemuan manusia atau imajinasi. Kata mencipta artinya adalah menyebabkan ada, menghadirkan, menerbitkan, memproduksi. Sementara itu, kreatif dicirikan dengan orisinalitas dan bersifat ekspresif. Meskipun pada dasaranya kreativitas penting bagi setiap orang, namun tak semua individu memiliki kreativitas tinggi karena bakat dan kreativitas yang dipunyai oleh masing-masing orang tentu saja berbeda-beda (Munandar, 2001)

Konsep kemampuan diambil dari kata competence dari Bahasa Inggris yang berarti kesanggupan, kewibawaan, kewenangan, kecakapan, dan kekuatan. Kata kemampuan dapat juga diartikan sebagai keterampilan yang dimiliki seseorang dalam menguasai sesuatu. Di dalam pembelajaran, penguasaan keterampilan tentu saja dibutuhkan supaya kegiatan belajar mengajar menjadi lebih menyenangkan dan terarah (Porter, 2000). Tiap peserta didik membutuhkan kemampuan dalam melakukan suatu kegiatan. Sama seperti yang diungkapkan oleh Robbins (2001), kemampuan yaitu kapasitas individu guna melakukan berbagai tugas dalam pekerjaan. Dengan kata lain, seseorang memilki kemampuan apabila dia bisa melakukan tugas yang diberikan.

Berdasarkan pemaparan sebelumnya bisa disimpulkan bahwa kemampuan berpikir kreatif memiliki posisi krusial pada kegiatan belajar mengajar, termasuk dalam pembelajaran sejarah. Namun, apakah kemampuan berpikir kreatif ini akan optimal jika dipadukan dengan semua metode atau model pembelajaran? Ataukah ia hanya cocok untuk model pembelajaran tertentu seperti PBL agar dapat meningkatkan hasil belajar sejarah? Terkait dengan hal ini, telah ada berbagai penelitian sejenis yang menjadi pijakan bagi kami untuk melakukan riset lebih lanjut terkait kemampuan berpikir kritis, model PBL serta hasil belajar sejarah.

Penelitian sejenis pernah dilakukan Lestari (2016) menunjukkan pengaruh model pembelajaran dan kemampuan berpikir kreatif dalam mengoptimalkan learning outcomes untuk pelajaran sejarah. Para murid yang punya critical thinking skills dan mengalami model pembelajaran sinektik rupanya menunjukkan learning outcomes yang lebih tinggi dibanding siswa yang mengikuti model 
pembelajaran kooperatif tipe group investigasi. Studi Lestari ini tidak menggunakan model pembelajaran PBL. Oleh karenanya kami sebagai peneliti merasa perlu untuk melakukan investigasi lebih lanjut.

Studi yang dilakukan oleh Rahayu (2019) mengindikasikan adanya perbedaan hasil belajar pada siswa kelas eksperimen yang mendapatkan perlakuan pembelajaran dengan model PBL dan siswa kelas kontrol yang mendapatkan perlakuan pembelajaran sejarah dengan menggunakan pendekatan saintifik di kelas XI IPS. Namun, penelitian yang dilakukan oleh Rahayu tidak meneliti kemampuan berpikir kreatif.

Penelitian terkait PBL juga pernah dipublikasikan oleh Widiyarti, dkk (2018) yang menunjukkan bahwa implementasi PBL bisa meningkatkan critical thinking skill peserta didik. Penelitian yang Widayarti dkk lakukan pada mata pelajaran Biologi ini menjadi salah satu pijakan bagi peneliti untuk melakukan investigasi serupa pada matapelajaran sejarah di SMA.

Berdasarkan berbagai paparan dan argumentasi sebelumya, maka kajian yang kami lakukan bertujuan untuk melihat pengaruh PBL dan berpikir kreatif atau critical thinking terhadap hasil belajar atau learning outcomes mata pelajaran sejarah para siswa SMA KORPRI Bekasi. Terkait dengan hal tersebut, peneliti merumuskan masalah sebagai berikut. Pertama, apakah ada perbedaan hasil belajar sejarah antara siswa yang diajar dengan menggunakan model PBL dengan siswa yang diajar dengan menggunakan model pembelajaran langsung? Kedua, apakah ada pengaruh interaksi antara model pembelajaran dengan kemampuan berpikir kreatif siswa? Ketiga, apakah ada perbedaan hasil belajar sejarah antara siswa yang memiliki kemampuan berpikir kreatif tinggi dan menggunakan model pembelajaran PBL dengan siswa yang menggunakan model pembelajaran langsung? Keempat, apakah ada perbedaan hasil belajar sejarah antara siswa yang memiliki kemampuan berpikir kreatif rendah dan menggunakan model pembelajaran PBL dengan siswa yang menggunakan model pembelajaran langsung?

\section{METODE}

Riset yang kami lakukan ini memiliki tujuan untuk menginvestigasi pengaruh model PBL dan kemampuan berpikir kreatif terhadap hasil belajar sejarah para siswa di SMA KORPRI Bekasi. Metode dalam studi ini ialah eksperimen dengan desain Treatment by level $2 \times 2$. Dalam riset ini, variabel bebasnya ialah model pembelajaran serta kemampuan berpikir kreatif, sedangkan variabel terikatnya ialah hasil belajar sejarah. Studi yang kami lakukan ialah riset eksperimen dengan menggunakan satu kelas eksperimen yang mendapatkan perlakuan berupa pembelajaran sejarah dengan model PBL dan satu kelas kontrol dengan model pembelajaran langsung.

Teknik pemilihan sampel acak diterapkan pada riset ini. Sampel berasal dari populasi siswa kelas X IIS SMA KORPRI Bekasi. Sebanyak 60 siswa dari sekolah tersebut terlibat sebagai subyek dalam riset ini. Mereka kemudian dibagi menjadi dua kelompok yang masing-masing terdiri dari 30 siswa. Kelompok pertama digunakan sebagai kelas eksperimen yang mendapat perlakuan 
pembelajaran sejarah model PBL dan kelompok yang lain menjadi kelas kontrol yang dikenakan perlakuan pembelajaran sejarah dengan model pembelajaran langsung.

Data riset kami mencakup hasil belajar siswa pada kelas eksperimen dan kontrol yang diperoleh melalui penggunaan soal pilihan ganda sebagai instrument untuk mengukur hasil belajar sejarah dan data kemampuan berpikir kreatif siswa yang kami dapatkan dengan menyebar angket dengan bentuk skala Likert (1-5). Sebelum digunakan, soal pilihan ganda diuji terlebih dahulu kevalidannya menggunakan rumus Point Biserial Correlation. Sementara itu pengujian reliabilitas soal pilihan ganda sebagai instrument penelitian dilakukan dengan menggunakan Rumus KRzo. Pengujian validitas angket sebagai instrumen kemampuan berpikir kreatif dilakukan dengan memakai rumus korelasi Product Moment sedangkan uji reliabilitas dilakukan menggunakan rumus Alpha Cronbach.

Dari hasil instrumen kemampuan berpikir kreatif siswa di setiap kelas, peneliti kemudian memutuskan untuk mengategorikan $27 \%$ dari peringkat teratas sebagai kelompok siswa yang punya kemampuan berpikir kreatif tinggi dan 27\% dari ranking terbawah sebagai siswa yang punya kemampuan berpikir kreatif rendah. Sisanya 46\% dikategorikan sebagai siswa berkemampuan berpikir kreatif sedang. Pada konteks ini peneliti mengikuti protokol yang disarankan oleh Sugiyono (2015).

Data yang didapatkan dari kesemua instrumen penelitian kemudian kami analisis dengan menggunakan analisis deskriptif dan inferensial. Dalam studi yang kami lakukan ini, kami menampilkan tabel distribusi, histogram, rata-rata dan standard deviasi sebagai bagian dari analisis deskriptif. Selanjutnya, untuk pengujian normalitas data digunakan uji Liliefors. Pengujian homogenitas data kami lakukan dengan menggunakan uji Bartlett pada taraf nyata s a = 0,05. Analisis Variansi (ANAVA) kemudian dilakukan untuk menguji hipotesis, khususnya untuk menguji efek utama dan pengaruh interaksi antar varibel A dan B. Berikutnya, untuk melihat hasil perbedaan di antara kelompok perlakuan penelitian kami melakukan uji Tuckey.

\section{HASIL PENELITIAN}

Sebelum melakukan uji hipotesisis, data hasil belajar yang diperoleh dalam riset ini diuji persyaratan analisisnya. Hal ini dilakukan melalui uji normalitas dan homogenitas. Berdasarkan perhitungan yang kami laksanakan untuk uji coba persyaratan analisis dalam riset ini, ternyata didapati bahwa data yang kami dapatkan ialah data dengan distribusi normal serta berasal dari sampel yang homogen.

Uji normalitas kami lakukan menggunakan Uji Liliefors dengan menggunakan taraf signifikansi $a=0,05$. Kriteria yang kami gunakan dalam riset ini adalah bila Lhitung (Lo) lebih kecil dari Ltabel (Lt), maka bisa disimpulkan bahwa data hasil penelitian memilki distribusi normal. Hasil perhitungan uji normalitas dan homogenitas pada data hasil riset ini disajikan pada Tabel 1.

Hasil perhitungan yang kami sajikan pada Tabel 1 menunjukan nilai Liliefors hasil perhitungan (Lo) untuk semua data ternyata lebih kecil dari Liliefors tabel (Lt). Berdasarkan data pada Tabel 1 ini 
maka bisa disimpulkan bahwa sampel riset ini berasal dari populasi yang berdistribusi normal. Oleh karenanya, persyaratan normalitas telah terpenuhi.

Tabel 1. Hasil Uji Normalitas (Liliefors) Hasil Belajar Sejarah

\begin{tabular}{|c|c|c|c|c|c|}
\hline Kelompok & A & $\mathbf{N}$ & Lhitung & Ltabel & KET \\
\hline $\mathrm{A} 1$ & & 16 & 0,129 & 0,222 & Normal \\
\hline $\mathrm{A} 2$ & & 16 & 0,109 & 0,222 & Normal \\
\hline $\mathrm{A} 1 \mathrm{~B} 1$ & & 8 & 0,173 & 0,313 & Normal \\
\hline $\mathrm{A} 1 \mathrm{~B} 2$ & 0,05 & 8 & 0,149 & 0,313 & Normal \\
\hline $\mathrm{A} 2 \mathrm{~B} 1$ & & 8 & 0,125 & 0,313 & Normal \\
\hline $\mathrm{A} 2 \mathrm{~B} 2$ & & 8 & 0,127 & 0,313 & Normal \\
\hline
\end{tabular}

Selanjutnya, uji homogenitas diterapkan pada data kombinasi treatment antara model pembelajaran dengan kemampuan berpikir kreatif siswa (A1B1, A1B2, A2B1, dan A2B2). Sedangkan pengecekan normalitas data dilakukan menggunakan Uji Bartlett pada taraf signifikansi $\alpha=0,05$, di mana dk (1-a)(k-1). Kriteria yang kami gunakan dalam penelitian ini adalah jika nilai hitung lebih kecil dari nilai tabel maka varians semua kelompok bersifat homogen. Ternyata hasil perhitungan uji homogenitas varians kelompok kombinasi pada riset yang kami lakukan menunjukan X2hitung sebesar 2,179 sedangkan X2tabel sebesar 7,81. Perhitungan yang kami dapatkan ini mengindikasikan bahwa hasil tidak terdapat perbedaan varians antara keempat kelompok, atau dengan kata lain data yang kami dapatkan dalam riset ini bersifat homogen.

Tahapan berikutnya adalah uji hipotesis untuk menguji efek utama yaitu pengaruh model PBL dan model pembelajaran langsung terhadap hasil belajar sejarah, serta efek interaksi antara model pembelajaran dengan kemampuan berpikir kreatif berdasarkan data hasil belajar. Pengujian dilakukan dengan menggunakan analisis varians dua jalur (ANAVA 2 X 2). Data hasil uji hipotesis terhadap efek utama dan efek interaksi dapat dilihat pada Tabel 2.

Berdasarkan tabel uji ANAVA yang disajikan pada Tabel 2 maka hipotesis pertama, yaitu hasil belajar sejarah siswa yang menggunakan model pembelajaran PBL lebih tinggi dari hasil belajar siswa yang menggunakan model pembelajaran langsung, dinyatakan diterima dalam riset ini. Jika menilik Tabel 2, hasil perhitungan menunjukkan bahwa Fhitung untuk model PBL memiliki skor 20.558, dengan skor Ftabel 4,20 pada taraf nyatanya $\alpha=0,05$. Hal ini berarti nilai Fhitung > Ftabel yang bermakna bahwa ada perbedaan hasil belajar sejarah antara siswa yang diberi perlakuan model PBL dibandingkan dengan siswa yang diberikan perlakuan model pembelajaran langsung. 
Tabel 2. Hasil Perhitungan Analisis Varians Dua Jalur (ANAVA 2 X 2)

\begin{tabular}{ccccccccc}
\hline Sumber Variansi & Db & JK & RJK & & $F_{\text {hitung }}$ & \multicolumn{2}{c}{$F_{\text {tabel }}$} \\
\cline { 3 - 8 } & & & & & & & 0.05 & 0.01 \\
\hline Model Pembelajaran PBL & 1 & 1046.53 & 1046.53 & 20.558 & $* *$ & 4.20 & 7.64 \\
\hline Kemampuan Berpikir Kreatif & 1 & 282.03 & 282.03 & 5.540 & $*$ & 4.20 & 7.64 \\
\hline Interaksi & 1 & 3982.78 & 3982.78 & 78.238 & $* *$ & 4.20 & 7.64 \\
\hline Dalam & 28 & 1425.38 & 50.91 & & & & \\
\hline Total Direduksi & 31 & 6736.72 & & & & & \\
\hline
\end{tabular}

Jika ditilik rerata hasil belajar sejarah kelompok yang mendapat perlakuan model PBL (A1) adalah 69.63, sementara itu kelompok yang mendapat perlakuan model pembelajaran langsung (A2) mempunyai rerata hasil belajar 58.19. Hal ini menunjukkan dengan jelas bahwa bahwa rerata nilai hasil bekara kelompok yang mendapat perlakuan model PBL lebih tinggi dari rerata nilai hasil bejar siswa yang mendapat perlakuaan pembelajaran langsung. Oleh karenanya, uji hipotesis pertama membuktikan bahwa H1 diterima dan Ho ditolak.

Uji hipotesis yang kedua ternyata juga mengindikasikan ada pengaruh interaksi antara penerapan model pembelajaran dan kemampuan berpikir kreatif terhadap hasil belajar sejarah para siswa. Hasil perhitungan ANAVA (lihat Tabel 2) memperlihatkan interaksi mempunyai skor Fhitung = 78.238 dan skor Ftabel = 4,20 pada taraf nyata $\alpha=0,05$. Dengan demikian bisa ditarik simpulan bahwa terdapat hubungan yang sangat signifikan antara penerapan model pembelajaran dan kemampuan berpikir kreatif terhadap hasil belajar sejarah siswa.

Grafik Interaksi antara model pembelajaran dengan kemampuan berpikir kreatif siswa terhadap hasil belajar sejarah pada siswa SMA KORPRI Bekasi ditampilkan pada Gambar 1.

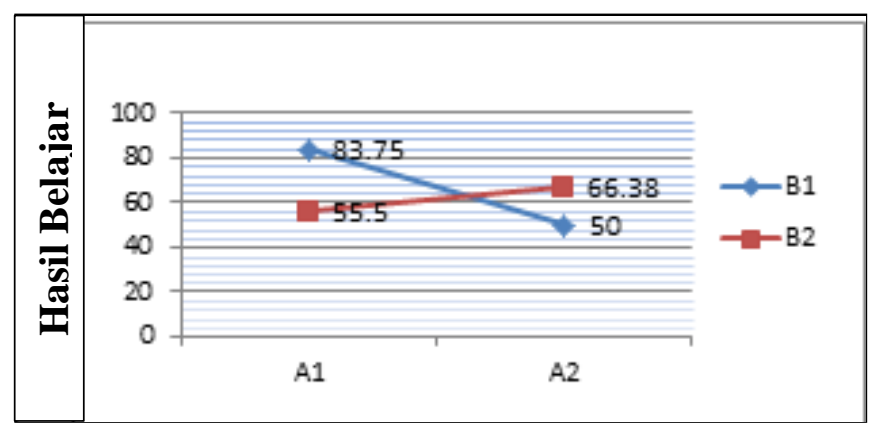

Gambar 1. Grafik Interaksi antara Model Pembelajaran Problem Based Learning dengan Kemampuan Berpikir Kreatif Siswa 
Uji hipotesis ketiga merupakan tahap lanjut dari uji terhadap interaksi yang dilakukan dengan Uji Tuckey untuk menguji taraf signifikannya. Hal ini untuk menguji hipotesis kami yang ketiga yaitu hasil belajar sejarah siswa yang menggunakan model pembelajaran PBL lebih tinggi dari siswa yang menggunakan model pembelajaran langsung pada siswa yang memiliki kemampuan berpikir kreatif kategori tinggi. Setelah dilakukan uji Tuckey maka diperoleh hasil sebagaimana disajikan pada Tabel 3.

\begin{tabular}{ccc}
\begin{tabular}{l} 
Tabel 3. Rangkuman Hasil Uji Tuckey Hipotesis Ketiga \\
\hline $\begin{array}{l}\text { Kelompok yang } \\
\text { dibandingkan }\end{array}$
\end{tabular} & Qhitung & Qtabel \\
\cline { 3 - 3 } & & $\alpha=0,05$ \\
\hline A1B1 dan A2B1 & 13.38 & 4,04
\end{tabular}

Tabel 3 menunjukan skor Qhitung lebih besar dari Qtabel pada taraf nyata $a=0,05$. Dengan demikian kami menyimpulkan bahwa ada perbedaan yang signifikan antara rerata hasil belajar atau learning putcomes mata pelajaran sejarah di kelompok siswa yang memiliki kemampuan berpikir kreatif tinggi yang mendapat perlakuan model pembelajaran PBL (A1B1) dengan kelopok siswa yang mendapat perlakuan model pembelajaran langsung (A2B1). Berdasarkan perhitungan yang kami lakukan, kami juga membuktikan bahwa rerata $\mathrm{A}_{1} \mathrm{~B}_{1}$ (83.75) lebih besar dari rerata $\mathrm{A}_{2} \mathrm{~B}_{1}$ (50.00). Oleh karena itu kami memutuskan bahwa hipotesis ketiga dapat dinyatakan diterima.

Hipotesis keempat pada riset kami ialah hasil belajar sejarah siswa yang mendapat perlakuan model PBL lebih rendah dari siswa yang mendapat perlakuan model pembelajaran langsung pada kelompok siswa berkemampuan berpikir kreatif tingkat rendah. Setelah dilakukan Uji Tuckey maka didapatkan hasil yang kami sajikan pada Tabel 4.

Tabel 4. Rangkuman Hasil Uji Tuckey Hipotesis Keempat

\begin{tabular}{ccc}
\hline $\begin{array}{c}\text { Kelompok yang } \\
\text { dibandingkan }\end{array}$ & Qhitung & Qtabel \\
\cline { 3 - 3 } & & $\alpha=0,05$ \\
\hline A1B2 dan A2B2 & 4.31 & 4,04 \\
\hline
\end{tabular}

Tabel 4 menunjukkan skor Qhitung lebih besar dari Qtabel pada taraf nyata $\alpha=0,05$. Berdasarkan hal tersebut, kami menyimpulkan bahwa ada perbedaan yang signifikan antara rerata hasil belajar sejarah kelompok siswa yang berkemampuan berpikir kreatif rendah dan mendapat perlakuan model pembelajaran PBL (A1B2) dengan yang medapat perlakuan model pembelajaran langsung (A2B2). Perhitungan kami menunjukkan pula rerata $A 2 B 2(66.38)$ ternyata lebih tinggi dari retata $A 1 B 2(55,50)$. Oleh karena itu hipotesis keempat juga dapat dibuktikan. 


\section{PEMBAHASAN}

\section{Pengaruh Model PBL Terhadap Hasil Belajar Sejarah Siswa}

Hasil uji hipotesis yang pertama memperlihatkan adanya pengaruh signifikan dari model PBL terhadap hasil belajar sejarah siswa. Oleh karenanya, PBL bisa dianggap bisa mengoptimalkan hasil belajar sejarah jika dibandingkan dengan pembelajaran langsung. Temuan pertama yang kami dapatkan dalam riset ini selaras dengan temuan sebelumnya dari Rahayu (2019) yang menyimpulkan adanya perbedaan learning outcomes mata pelajaran sejarah pada siswa yang diajar menggunakan model PBL dan siswa yang diajar memakai pendekatan saintifik. Perbedaan dalam riset tersebut ditunjukkan dari uji kontrol yang menggunakan independent $t$-test dari tiga kompetensi hasil belajar. Hasil uji independent t-test yang dilakukan oleh Rahayu (2019) tersebut mengindikasikan jika ada pengaruh model PBL terhadap hasil belajar siswa yang berupa adanya perubahan hasil belajar siswa.

Penerapan PBL sepertinya lebih baik digunakan pada pembelajaran sejarah di kelas karena model ini ternyata bisa melibatkan siswa secara aktif dan merangsang siswa agar mengembangkan kapabilitas dalam memroses informasi dan merumuskan pemahamannya sendiri terhadap materi atau konsep yang dipelajari. Melaui penerapan model PBL, siswa dilatih memilih, memilah dan mengolah serta mengevaluasi berbagai informasi yang didapatkan. Mereka tidak hanya pasif dalam pembelajaran, melainkan lebih aktif. Para siswa yang memiliki kemampuan menafsirkan informasi akan bisa memperoleh pengetahuan yang saling terkoneksi, serta bisamemperoleh pembelajaran yang bermakna.

\section{Pengaruh Interaksi Model Pembelajaran dengan Kemampuan Berpikir Kreatif}

Hasil uji hipotesis kedua memperlihatkan ada pengaruh interaksi antara model pembelajaran yang digunakan dalam pembelajaran sejarah di SMA KORPRI Bekasi dengan kemampuan berpikir kreatif siswa yang selanjutnya juga berpengaruh terhadap hasil belajar sejarahnya. Temuan kami selaras dengan studi oleh Lestari (2020) yang juga menunjukkan adanya pengaruh interaksi antara penggunaan model pembelajaran dan kemampuan berpikir kreatif terhadap hasil belajar sejarah peserta didik. Jika dlihat dari data pada Tabel 2, Fhitung untuk faktor interaksi (42, 952) lebih besar daripada Ftabel $(4,20)$ pada taraf nyata $\alpha=0,05$. Hal ini memperlihatkan adanya pengaruh interaksi antara penggunaan model pembelajaran dan kemampuan berpikir kreatif peserta didik terhadap learning outcomes peserta didik (Lestari, 2020).

Model pembelajaran yang sesuai dapat memicu rangkaian kegiatan pembelajaran yang bermaknsa dan bisa meningkatkan hasil belajar sejarah para siswa. Sementara itu, critical thinking atau berpikir kreatif akan menstimulasi siswa agar bisa berinovasi, selanjutnya melakukan analisis serta mengambil keputusan berdasarkan informasi yang telah didapatkan sebelumnya.

Kemampuan berpikir kreatif sebagaimana telah dibahas pada bagian sebelumnya merupakan kebutuhanbagi generasi milenial. Melalui berbagai kegiatan belajar mengajar yang memfokuskan pada pemrosesan informasi dan kemampuan berpikir kreatif, para siswa bisa menggali berbagai data 
dan informasi mengenai sejarah yang akan meningkatkan pemahamannya terhadap peristiwaperistiwa yang terjadi di masa lalu dan dapat memunculkan kesadaran sejarah dalam dirinya.

\section{Pengaruh PBL pada Siswa dengan Kemampuan Berpikir Kreatif Tinggi}

Uji hipotesis ketiga memperlihatkan PBL memiliki pengaruh yang signifikan dan cocok untuk peserta didik atau siswa yang berkemampuan berpikir kreatif tinggi. Temuan kami ini sesuai dengan kajian sebelumnya dari Widiyarti, dkk (2018) yang menunjukkan bahwa PBL bisa meningkatkan keterampilan berpikir kreatif siswa. Kriteria penilaian semua indikator dalam berpikir kreatif meningkat. Para peserta didik yang mengalami kegiatan belajar dengan model PBL juga cenderung mempunyai kemandirian lebih baik jika dibandingkan dengan siswa yang diajar dengan ceramah. Ketercapaian keterampilan berpikir kreatif para peserta didik atau para siswa pada kelas yang menerapkan PBL ternyata cenderung lebih baik jika dibandingkan dengan para siswa pada kelas tanpa menerapkan pembelajaran PBL (metode ceramah). Nilai N-Gain untuk keterampilan berpikir kreatif pada kelas eksperimen adalah 0,66 (sedang) dan pada kelas kontrol ialah 0,36 (sedang). Temuan ini mengindikasikan bahwasannya penerapan PBL bisa meningkatkan kemampuan berpikir kreatif dan kemandirian peserta didik (Widiyarti, dkk 2018).

Temuan ini kemungkinan berkaitan dengan fakta bahwa PBL merupakan pembelajaran yang melibatkan kegiatan dan proses pengolahan informasi. Oleh karena itu, peserta didik yang termasuk dalam kategori berkemampuan berpikir kreatif tinggi pada akhirnya memiliki keunggulan dalam mengorganisasikan serta menciptakan kebutuhan, dan menyimpulkan berbagai macam informasi yang diperoleh dalam kegiatan belajar mengajar. Kemampuan berpikir kreatif tinggi ternyata mempengaruhi kemampuan siswa dalam memahami materi pembelajaran sehingga bisa mendapatkan tingkat kreatifitas yang lebih tinggi. Sementara itu pada pembelajaran langsung, siswa atau peserta didik yang berkemampuan berpikir kreatif tinggi, walaupun bisa memahami informasi dari pendidik, akan tetapi tak secara penuh melibatkan kemampuan berpikir kreatifnya pada kegiatan pembelajaran.

\section{Pengaruh PBL pada Siswa dengan Kemampuan Berpikir Kreatif Rendah}

Hasil pengujian hipotesis terakhir memperlihatkan kelompok siswa yang memiliki kemampuan berpikir kreatif tingkat rendah dan diberi perlakuan model pembelajaran langsung ternyata mempunyai hasil belajar yang lebih tinggi jika dibandingkan pada siswa serupa yang diberi perlakuan pembelajaran model PBL. Temuan ini selaras dengan riset sebelumnya oleh Prasetya (2017). Dalam penelitiannya, ia menyimpulkan ada perbedaan hasil belajar sejarah siswa berkemampuan kreatif level rendah yang diajar dengan menerapkan metode pembelajaran pemecahan masalah dengan siswa dengan kemampuan berpikir kreatif rendah yang diajar dengan menggunakan metode pembelajaran konvensional (Prasetya, 2017).

Temuan kami bersangkutan dengan fakta bahwa rangkaian pembelajaran langsung tidak menutut kapabilitas untuk bisa berpikir kreatif. Ini karena para peserta didik cederung pasif dalam menampung segala informasi atau pengetahuan yang disajikan guru selama rangkaian kegiatan 
belajar mengajar di kelas. Hal ini ternyata lebih mudah bagi siswa dengan berkemampuan berpikir kreatif rendah. Terlebih, pembelajaran langsung yang didominasi dengan metode ceramah menyebabkan siswa berkemampuan berpikir kreatif rendah tidak sampai ke tahapan pengolahan informasi dan penciptaan inovasi, sebab mereka tidak diarahkan pada tanggung jawab memilih sumber, mengolah informasi dan menciptakan kreatifitas dari informasi yang didapat.

\section{KESIMPULAN}

Berdasarkan hasil temuan serta pembahasan sebagaimana diuraikan pada bagaian terdahulu maka kami dapat menarik beberapa kesimpulan dari riset ini. Pertama, hasil belajar sejarah siswa yang diberi perlakuan model pembelajaran PBL secara umum lebih tinggi jika dibandingkan dengan hasil belajar sejarah siswa yang diberikan perlakuan berupa model pembelajaran langsung. Kedua, ada pengaruh interaksi antara model PBL dan kemampuan berpikir kreatif siswa terhadap hasil belajar sejarah. Ketiga, hasil belajar sejarah siswa yang diajar yang memakai model pembelajaran PBL lebih tinggi dari pada hasil belajar sejarah siswa yang memakai model pembelajaran langsung, terutama pada siswa yang mempunyai kemampuan berpikir kreatif tinggi. Selaiknya, siswa yang memiliki kemampuan berpikir kreatif rendah ternyata memiliki hasil belajar lebih rendah jika menggunakan PBL dan lebih tinggi jika menggunakan pembelajaran langsung.

Ada beberapa implikasi dari kajian ini. Pertama, secara umum model pembelajaran PBL sesuai untuk diterapkan dalam pembelajaran sejarah sebab dapat meningkatkan kemampuan siswa untuk memahami serta mengolah informasi dan membentuk kemampuan berpikir yang lebih baik. Kedua, PBL lebih cocok untuk siswa berkemampuan berpikir kreatif tingkat tinggi daripada siswa berkemampuan kreatif rendah sehingga guru perlu mempertimbangkan kemampuan berpikir kreatif yang dimiliki siswa sebelum memilih dan menarapkan model pembelajaran tertentu. Pertimbangan ini perlu dilakukan mengingat tak semua model pembelajaran sesuai untuk semua karakter siswa (fit for all).

\section{DAFTAR PUSTAKA}

Amir, M. T. (2009). Inovasi Pendidikan Melalui Problem Based Learning. Jakarta: Prenada Media.

Astuti, R. P., \& Junaedi, I. (2013). Peningkatan Aktivitas Dan Hasil Belajar melalui PBL Pada Siswa Kelas X SMA. journal of education research, 42(2), 93-100.

Basri, H. (2013). Landasan Pendidikan. Bandung: Pustaka Setia.

Kuntowijoyo. (2013). Pengantar Ilmu Sejarah. Yogyakarta: Tiara Wacana.

Lestari, N. I. (2016). Pengaruh Model Pembelajaran dan Kemampuan Berpikir Kreatif Terhadap Hasil Belajar Sejarah Peserta Didik di SMA Negeri 30 Jakarta. Jurnal Pendidikan Sejarah, 5(1), 28-37.

Lestari, N. I. (2020). Pengaruh Model Pembelajaran Dan Kemampuan Berpikir Kreatif Terhadap Hasil Belajar Sejarah Peserta Didik Di SMA Negeri 30 Jakarta. Journal of Cahaya Mandalika, 1(1), 35-41. 
Munandar, U. (2001). Mengembangkan Kreativitas Pengalaman Hidup 10 Tokoh kreatif Indonesia. Jakarta: Yayasan Obor Indonesia.

Newman, M. J. (2005). Problem Based Learning: An Introduction and Overview of the Key Features of the Approach. Journal of Veterinary, 32(1), 12.

Porter, B. D. (2000). Quantum Teaching/Learning. Bandung: Kaifa.

Prasetya, Y. B. (2017). Pengaruh Metode Pembelajaran dan Kemampuan Berpikir Kreatif Terhadap Hasil Belajar Sejarah Siswa di SMA Negeri 5 Depok Kelas 11 IPS. Jurnal PENDIDIKAN SEJARAH, 6(2), 1-11.

Rahayu, E. P. (2019). Pengaruh Model Pembelajaran Problem Based Learning Terhadap Hasil Belajar Siswa kelas XI IPS Pada Mata Pelajaran Sejarah di SMAN 1 Tarik. Avatara e-Journal Pendidikan Sejarah, 7(3).

Reid, G. (2007). Motivating Learners in The Classroom; Ideas and Strategi. London: Paul Chapman Publishing.

Robbins, S. P. (2001). Prilaku Organisasi: Konsep, Kontroversi, Aplikasi. Jakarta: PT: Prenhallindo. Sayono, J. (2015). Pembelajaran Sejarah di Sekolah: Dari Pragmatis ke Idealis. Jurnal Sejarah dan Budaya, 7(1), 9-17.

Siregar, E., \& Nara, H. (2010). Teori Belajar dan Pembelajaran. Bogor: Ghalia Indonesia.

Sugiyono. (2015). Statistika Untuk Penelitian. Bandung: Alfabeta.

Suprijono, A. (2009). Cooperatif Learning Teori dan Aplikasi Paikem. Yogyakarta: Pustaka Pelajar. Susanto, A. (2013). Teori belajar dan pembelajaran di sekolah dasar. Jakarta: Kencana.

Tirtarahardja, U., \& La Sulo, S. L. (2005). Pengantar Pendidikan. Jakarta: Rineka Cipta.

Widiyarti, W., Riandi, \& Soetisna, U. (2018). Implementasi Pembelajaran Problem Based Learning (PBL) Untuk Meningkatkan Keterampilan Berpikir Kreatif dan Kemandirian Siswa. Jurnal Wahana Pendidikan, 5(2), 1-9.

Widja, I. G. (2018). Pembelajaran Sejarah yang Mencerdaskan. Jurnal Pendidikan Sejarah Indonesia, 1(2), 117-134.

Winkel. (2005). Psikologi Pendidikan. Yogyakarta: Media Abadi. 
JPSI, Vol 4, No. 1, 2021 | 2 